\title{
New record and distribution extension of Atractus paraguayensis Werner, 1924 (Serpentes: Dipsadidae)
}

\author{
Omar Machado Entiauspe-Neto ${ }^{1^{*}}$ and Arthur Diesel Abegg ${ }^{2}$

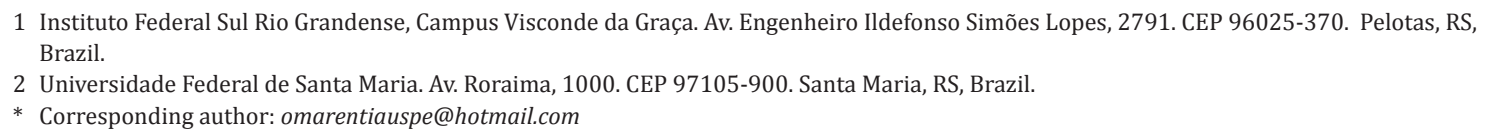

ABSTRACT: The dipsadid ground snake, Atractus paraguayensis, occurs in Southern Brazil, Southern Paraguay and Argentina. In this study, we report the most austral record of the species in Brazil, based on a specimen captured in Capão do Leão, in the campus of the Universidade Federal de Pelotas. This extends the species geographical distribution $354 \mathrm{~km}-\mathrm{south}$, of Colorado, Brazil, the most austral record of the species until now.

The ground dipsadid snakes genus, Atractus comprise nearly 140 cryptozoic and semi-fossorial species, most of them rare and with restrict distributions known only for the holotype (Passos and Fernandes 2008; Prudente and Passos 2008; Passos and Arredondo 2009; Passos et al. 2009 a,b,c,d,e,f, Passos et al. 2010). Thirty four species are known to occur in Brazil (Bérnils 2010), with four recorded to Rio Grande do Sul: A. paraguayensis Werner, 1924, A. reticulatus (Boulenger 1885), A. thalesdelemai Passos, Fernandes and Zanella, 2005, and A. zebrinus (Jan 1862) (Passos et al. 2010).

Atractus paraguayensis a small sized species (maximum SVL of $490 \mathrm{~mm}$ ) fossorial snake, known from

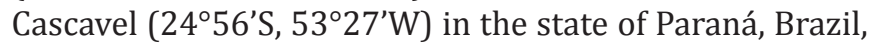
southward to Villa Urquiza ( $\left.31^{\circ} 39^{\prime} \mathrm{S}, 60^{\circ} 22^{\prime} \mathrm{W}\right)$ in the province of Entre Rios, Argentina (Passos et al. 2010).

In this study, we report the southernmost record of A. paraguayensis (CHR 023) in the state of Rio Grande do Sul, Brazil, based on a specimen from Capão do Leão municipality (3146'19" S 52²0'34" W), collected in 2001 by workers of the Universidade Federal de Pelotas (UFPEL), however, the method used for collection and euthanasia are unknown. We identified two possible southernmost registers of the species in the state of Rio Grande do Sul, based on the examination of specimens and literature. The first one is a specimen housed in the Coleção de Répteis da Universidade de Passo Fundo, from Pinheiro Machado (CRUPF 257, 31 ${ }^{\circ} 34^{\prime} 40^{\prime \prime} \mathrm{S} 53^{\circ} 22^{\prime} 51^{\prime \prime} \mathrm{W}$ ) and the other, is housed in the same collection, from Colorado (CRUPF 196, 28³1'26" S 5259'38” W). However, the specimen of Pinheiro Machado (CRUPF 257) need to be interpreted with cautious due to the possibility of reference to the Pinheiro Machado village (2941'58.22" S 5351'49.62" W), from the municipality of Santa Maria, where the authors observed the specimen of Atractus paraguayensis (Universidade Federal de Santa Maria, ZUFSM 2646). So we did not consider the specimen from of Pinheiro Machado (31 $\left.34^{\prime} 40^{\prime \prime} \mathrm{S} 53^{\circ} 22^{\prime} 51^{\prime \prime} \mathrm{W}\right)$ as a possible southernmost record, which was also the approach adopted in the study of Passos et al (2010) when delineating a distribution map of $A$. paraguayensis. The possibility of the specimen mark being overlapped by another specimen in the distribution map was discarded, considering that in the revision of Passos et al (2012), the specimen (CRUPF 257) was the only one labeled as being from Pinheiro Machado.

The specimen CHR 023 (Figure 1) is male, and has $15 / 15 / 15$ dorsal scale rows, two postocular scales, moderately sized loreal scale, $1+2$ temporal scales, seven infralabial scales, seven infralabial scales, three gular scale rows, 146 ventral scales and 32 subcaudal scales, head length of $16 \mathrm{~mm}$, snout-vent length of $318 \mathrm{~mm}$ and tail length of $46 \mathrm{~mm}$. Dorsum olive, with a single bluish vertebral line and venter is immaculate cream. This is the southernmost record of $A$. paraguayensis in the state of Rio Grande do Sul, and, therefore, Brazil, extending the species

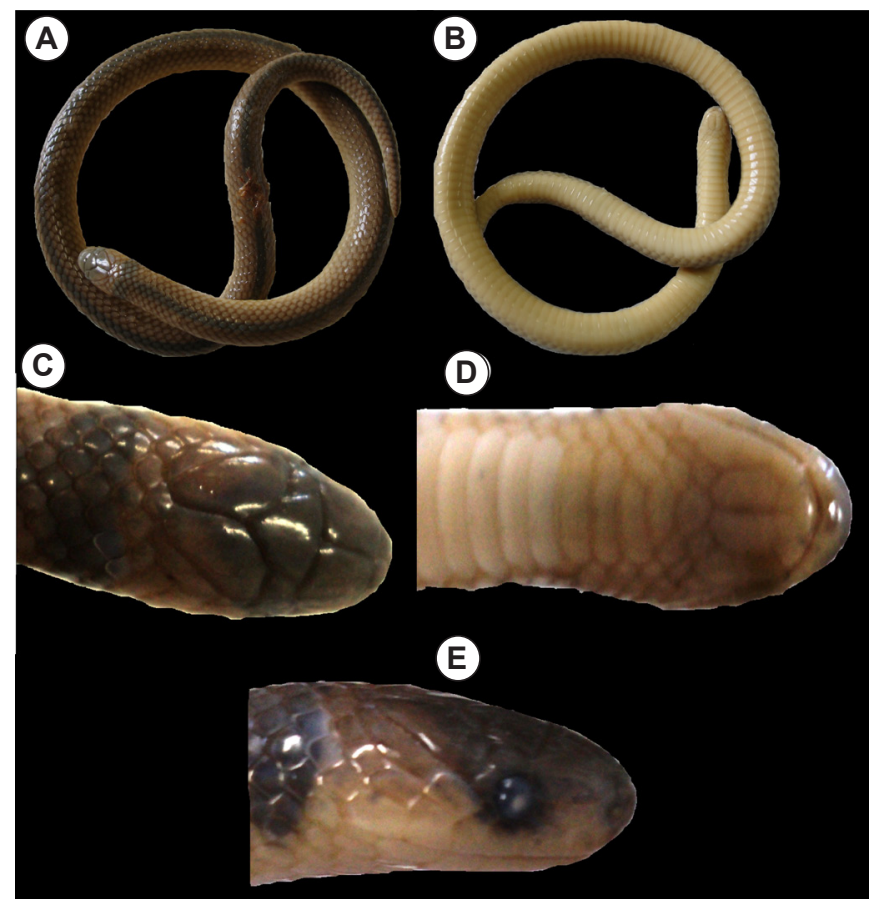

FIGURE 1. Head views of the specimen (CHR 023) of A. paraguayensis, collected in Capão do Leão, Rio Grande do Sul, Brazil. 
distribution $354 \mathrm{~km}$ - south of the previous southernmost locality- in the municipality of Colorado (Figure 2). This species also was registered to the locality of Corrientes, Argentina. Our record helps to delineate the distribution of
A. paraguayensis, showing that, the Northern and Central portion of Uruguay and Northern Corrientes in Argentina are distribution gaps that probably require more sampling effort.

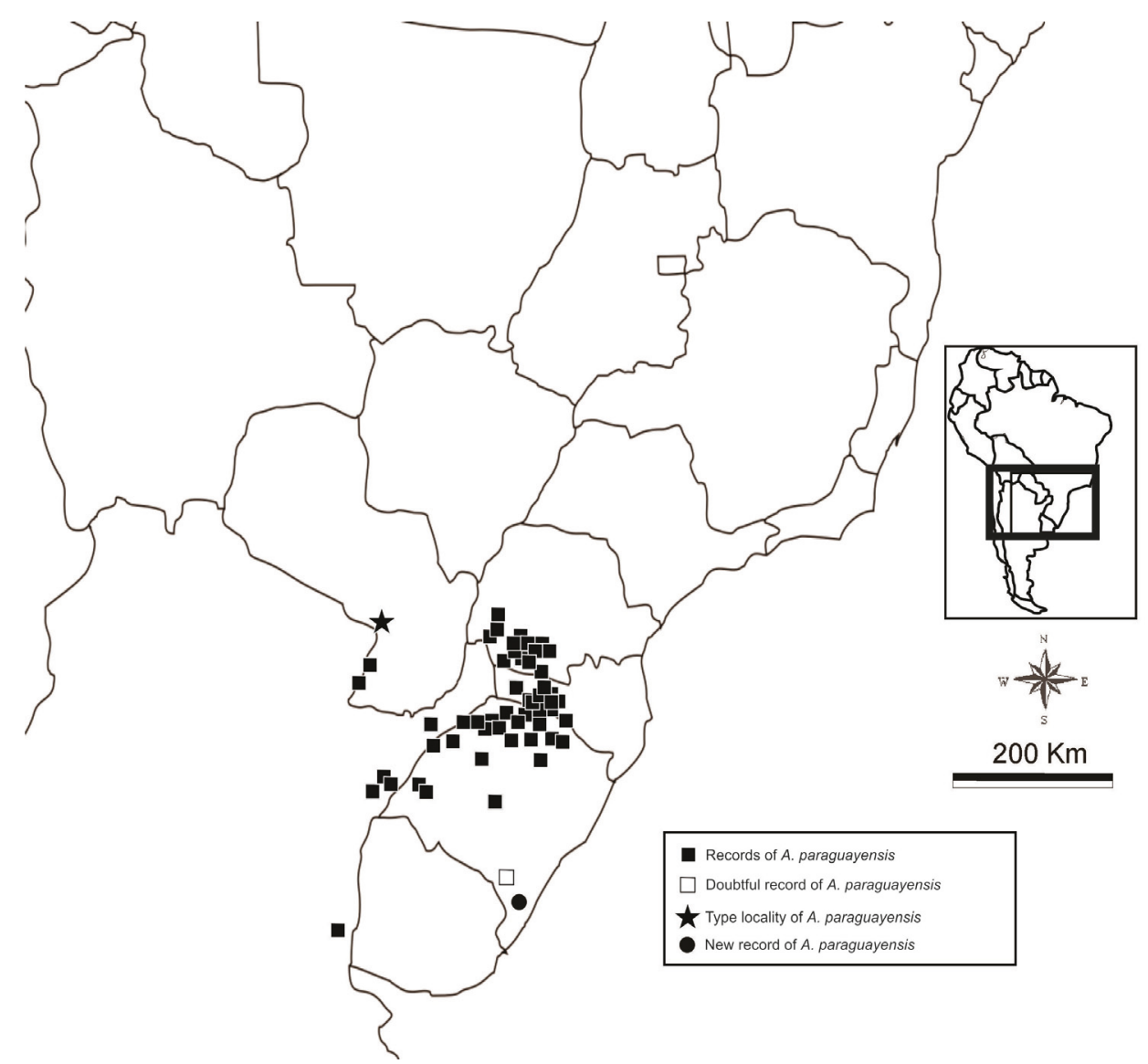

FIGURE 2. Distribution map of the species, made based on literature records of Passos et al (2012) and examined specimens from the collections ZUFSM and CHR.

AcKnowledgments: We are grateful to Prof. Thales de Lema for mentoring and helping us in our study and to Prof. José Eduardo F. Dornelles (UFPEL) for kindly permitting and helping with the examination of specimens under his care.

\section{Literature Cited}

Bérnils, R.S. (org.). 2010. Brazilian reptiles - List of species. Electronic database accessible at http://www.sbherpetologia.org.br/. Sociedade Brasileira de Herpetologia. Captured on 24 August 2012.

Cei, J.M. 1993. Reptiles Del noroeste, nordeste y este de la Argentina. Herpetofauna de las selvas subtropicales, Puna y Pampas. Museo Regionale di Scienze Naturali de Torino Monografia 15: 001-949.

Passos, P. and R. Fernandes. 2008. A new species of the colubrid snake genus Atractus (Reptilia: Serpentes) from the central Amazon of Brazil. Zootaxa 1849: 59-66.

Passos, P., J.D. Lynch, R. and Fernandes. 2009. Taxonomic status of Atractus sanctaemartae and A. nebularis, and description of a new Atractus from Atlantic coast of Colombia. Herpetological Journal 18(4): 175-186.

Passos, P., Rivas, G. and Barrio-Amoros, C. 2009. Description of two new species from Venezuela in the highly diverse dipsadine genus Atractus (Serpentes: Colubridae). Amphibia-Reptilia 30(2): 233-243.

Passos, P., Arredondo, J. C., Fernandes, R. and Lynch, J. D. 2009. Three new Atractus (Serpentes, Dipsadidae) from the Andes of Colombia. Copeia 2009 (3): 425-436.
Passos, P., Mueses-Cisneors, J. J., Lynch, J. D. and Fernandes, R. 2009. Pacific lowland snakes of the genus Atractus (Serpentes: Dipsadidae), with description of three new species. Zootaxa 2293: 1-34.

Passos, P., R. Aguayo and G. Scrocchi. 2009. Rediscovery of the rare Atractus bocki, with assessement of the taxonomic status of Atractus canedii (Serpentes: Colubridae: Dipsadinae). Journal of Herpetology 43(4): 710-715.

Passos, P. and J.C. Arredondo. 2009. Rediscovery and redescription of the Andean earth-snake Atractus wagleri (Reptilia: Serpentes: Colubridae). Zootaxa 1969: 59-68.

Passos, P., R. Fernandes, R.S. Bérnils and J.C. Moura-Leite. 2010. Taxonomic revision of the Brazilian Atlantic Forest Atractus (Reptilia: Serpentes: Dipsadidae). Zootaxa 2364: 1-63.

Passos, P., R. Fernandes and N. Zanella. 2005. A new species of Atractus (Serpentes: Colubridae) from Southern Brazil. Herpetologica 61: 209-218.

Prudente, A.L.C. and P. Passos. 2008. New species of Atractus Wagler, 1828 (Serpentes: Dipsadinae) from Guyana Plateau in northern Brazil. Journal of Herpetology 42(4): 723-732.

RECEIVED: August 2012

ACCEPTED: November 2012

Published ONLINE: March 2013

EDITORIAL RESPONSIBILITY: Fernanda Werneck 


\title{
New record and distribution extension of Atractus paraguayensis Werner, 1924 (Serpentes: Dipsadidae)
}

\author{
Omar Machado Entiauspe-Neto ${ }^{1^{*}}$ and Arthur Diesel Abegg ${ }^{2}$ \\ 1 Instituto Federal Sul Rio Grandense, Campus Visconde da Graça. Av. Engenheiro Ildefonso Simões Lopes, 2791. CEP 96025-370. Pelotas, RS, \\ Brazil. \\ 2 Universidade Federal de Santa Maria. Av. Roraima, 1000. CEP 97105-900. Santa Maria, RS, Brazil. \\ * Corresponding author: omarentiauspe@hotmail.com
}

\section{ERRATUM}

According to Noeli Zanella (pers. comm.), curator of the Amphibian and Reptile collections of Universidade de Passo Fundo, 1) the specimen CRUPF 257 labeled as from "Pinheiro Machado" by Passos et al. (2010) and us, was collected in Pinheiro Marcado, Carazinho (28 $8^{\circ} 7^{\prime} 02^{\prime \prime} \mathrm{S}$, $52^{\circ} 47^{\prime} 11^{\prime \prime}$ W); 2) The correct label of the specimen from Colorado is CRUPF 1196, not CRUPF 196.

Finally, we inform that in-text citations of Passos et al. (2012) should be read as Passos et al. (2010).
We regret these errors. 